\title{
タイ国及びマレーシア連邦の紙パルプエ業の現況
}

一一技術援助・国際研究協力の観点から—

工業技術院四国工業技術試験所 小 林 良 生

\section{The Present Situation of Pulp and Paper Industries in Thailand and Malaysia}

\author{
From the Viewpoints of their Requests for Technical \\ Assistance and International Research Co-operation Projects.
}

\author{
Yoshinari Kobayashi \\ Government Industrial Research Institute, Shikoku
}

\section{1.はじめに}

筆者は昭和 52 年 3 月標題 2 力国を訪問し，紙パル プ産業に関する国際矿究協力についての事前調査を行 なった。国際研究協力事業（工業技術院では総務部园 際研究協力官室で担当しているが，将来国際研究協力 研究所に昇格させる含みで, Institute for Transfer of Industrial Technology の略称として ITIT 事業 と呼称している）とは，工業技術院が同院所属の 16 試験所の鉣工業分野のポテンシャルを效果的に発展途 上国に移転するための制度で, 1973 年から発足した。 ITIT 事業の対象国は現在では先進国も含まれるが, 発足時の目仢にかんがみ主体は発展途上国である。特 に，東南アジア諸国が中枢を占める。東南アジア諸国 は, 田中 ${ }^{1)} に よ る と$ 紙パルプの需給関係から4つのグ ループに分類される：(1) 需要の大半を自国産により 自給している国一一国, 台湾, 韓国, (2) 生産の一部 を輸出に振り向けている国一中国, 台湾, (3) 自国 で生産しているが, 不足分又は生産能力のない品質を 輸入している国一タイ国，ベトナム，フィリピン， インドネシア, マレーシア連邦, (4) 生産は全くなく, 需要の全部を輸入に頼っている国一一香港, シンガポ 一ル。ところで, 研究協力対象国としては, 自国の紙 パルプ技術の発展拡大を要請している国であり, 上記 分類では(3)が妥当であり, このうち, 工業技術院で ITIT 事業を既に多く央施しているフィリピン, イン ドネシアを除くことになり, 消去法的に標題 2 力国が 選定された。標題 2 力国の紙パルプ工業の事情は, 古 〈は関 ${ }^{2)}$, 田中 ${ }^{1)}$, 小泉 ${ }^{3)}$, 比較的新しくは森 ${ }^{4}$ によっ
て紹介されてはいるが，既に報告以来 7 年以上の歳月 が流れている。そこで, 比較的新しい情報を含め, 重 点を技術援助・研究協力を主体にしてご紹介すること にしたい。

\section{2.タイ国}

\section{1 紙パルプエ業の現況}

タイ国の紙需要量は 1972 年で $222,000 \mathrm{t}, 1976$ 年 では $250,000 \mathrm{t}$ といわれ, 人口約 40 百万として, 1 人 当りの消費量はわずかに $6.25 \mathrm{~kg} /$ 年である。我が国の 1975 年の紙・板紙消費量が $173.7 \mathrm{~kg} /$ 年である 著しく低い值であることは一目りょら然である。この 需要量の内訳は偟業用紙 $50 \%$, 新聞用紙 $25 \%$, 印刷 用紙 $15 \%$, 薄葉紙 $5 \%$ その他 $5 \%$ である。この総需 要量の約半分が自国内の生産, 残りはすべて輸入であ る。国内の紙の生産量は 1972 年 $132,000 \mathrm{t}$ でといわ れる。タイ国内の主要な紙パルプ工場は表 1 に示す通 りであるが，その生産能力は 1973 年に発行された資 料から得たものである（従って，本文中の数値と若干 の食い違いの見られるところがある)。一般的に言っ て，価格の高騰と 1974〜76 年にわたる不涊のため, 上質印刷用紙の需要が減り, 在庫が増え, 産業用紙も 生産過剩であり，不足しているのは新聞用紙である。 この不足は輸入でまかなわれ，輸入紙の大半を新聞用 紙で占める。1976 年の 輸入実績は 65,000 t である。 上質紙はカナダ，スウェーデン，安ものは中国，台湾 からの輸入である。輸入紙の大半を占める新聞用紙は, 不足気味のため, 価格が急上昇し 1972 年 52.5 円 $/ \mathrm{kg}$, 1973 年 75 円 $/ \mathrm{kg}, 1974$ 年には 120 円 $/ \mathrm{kg}$ となり, し 
Table 1 Main Pulp and Paper Mill in Thailand

\begin{tabular}{|c|c|c|c|}
\hline Group & Name of Pulp and Paper Mill & Kind of Production & $\begin{array}{c}\text { Capacity } \\
\text { (t/year) }\end{array}$ \\
\hline \multirow{13}{*}{ A } & Bangkok Paper Mill & $\begin{array}{l}\text { Printing Paper, Writing Paper } \\
\text { Wrapping Paper }\end{array}$ & 14,000 \\
\hline & Thai Union Paper Mill & Wrapping Paper, White Board & 20,000 \\
\hline & Saiam Kraft Paper & Kraft Paper, Bagasse Pulp & 54,000 \\
\hline & Bang Pa-in Paper Mill & Printing Paper, Writing Paper & 12,000 \\
\hline & & Rice Straw Pulp & \\
\hline & Thai Card Board & Card Board & 7,200 \\
\hline & Dhanachoti & Printing Paper, Writing Paper & 4,500 \\
\hline & & Carbon Paper & \\
\hline & Siam Paper & Air Mail Paper, Tracing Paper & 3,000 \\
\hline & Kimberly Clerk & Tissue Paper & 4,800 \\
\hline & Thai Scott Paper & Tissue Paper & 4,500 \\
\hline & Mae Num Paper Ind. & Tissue Paper & 2,000 \\
\hline & & Total & 126,000 \\
\hline \multirow{16}{*}{ B } & Roong Fah Ind. & Card Board & 1,000 \\
\hline & Krung Thong Paper Products & Straw Paper, Handmade Tissue Paper & 1,000 \\
\hline & Thai Parer Products Ind. & Straw, Paper, Card Board & 1,200 \\
\hline & Thai Kanchanaburi Paper Mill & Printing Paper from Bamboo Pulp & 3,000 \\
\hline & Thai Charoen Taii & $\begin{array}{l}\text { Wrapping Paper, Handmade Tissue } \\
\text { Paper }\end{array}$ & 764 \\
\hline & Krung Thon Paper Ind. & Card Board & 720 \\
\hline & Sri Thai Ind. & Straw Paper & 620 \\
\hline & Luk Si Paper Factory & Card Board, Wrapping Paper & 680 \\
\hline & Yu Heng Ind. & Card Board & 360 \\
\hline & Krung Thai Ind. & Card Board & 250 \\
\hline & Asia Card Board Factory & Card Board & 240 \\
\hline & CEM Co. & Card Board & 170 \\
\hline & South East Asia Card Board & Card Board & 96 \\
\hline & Mr. Prayat Klongsiri (Chieng Mai) & Straw Paper (Handmade) & 300 \\
\hline & Chieng Mai Paper Factory & Straw Paper (Handmade) & 180 \\
\hline & & Total & 10,560 \\
\hline
\end{tabular}

Note. Mills belonging to A group are eligible for promotions from Board of Investigation by Investment Promotion Acts and B group Mills do not receive promotions by the Acts. 
かも，輸入量も年々上昇する傾向にある。そのため， 自国内での新聞用紙製造の要請は大きい。国営の製紙 工場としては Bang Pa-in Mill, Sri Siam Paper Mill, Bangkok Paper Mill がある。これらの工場で の上質紙の生産量は 1976 年では $13,422 \mathrm{t}$ で, 1974 年 の生産量の半分である。総生産量は現在では $50,000 \mathrm{t}$ （表 1 とは多少異なる）といわれているから，著しく 減産している。この中でも Sri Siam が最も悪く, 1976 年はわずかに $41 \mathrm{t}$ の上質紙を製造したに過ぎな い。そこで，自国の資源に恵まれた稻わらパルプなど 非木材パルプ紙に力を入れている。竹パルプを使用し た印刷用紙工場は Kanchanaburi Paper Mill で, 能 力は $3,000 \mathrm{t} /$ 年である。

上質紙にてきかえ, 産業用紙の需要は大きい。主要 なクラフト紙製造会社は 6 社あり，その総生産能力は $175,000 \mathrm{t} /$ 年, でその最大のものは Siam Kraft 社で ある。産業保護政策のため, クラフト紙の輸入は禁止 措置をとっている。

薄葉紙の生産は, タイ国では遅かったが, 最も成 功しててる分野である。主要な会社としては, Mae Nam Paper Industries, Kimberly Clerk, Thai Scott Paper, Krung Thon Paper Products 等であ り，その生産総能力は $16,000 \mathrm{t} /$ 年，稼動はその $70 \%$ で, 1975 年の生産実績は $10,800 \mathrm{t}, 1976$ 年はその 10 \%増しである。

\section{2 パルプ資源}

タイ国のパルプ資源は極めて豊富で，同国の資源だ けで, 東南アジア全体のパルプをまかなうことができ
るといわれ，そのなかで，放重されている稲わら，と

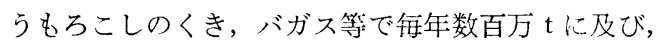
これだけでも自国の紙パルプの消費を自給できる。そ のため, 同国の研究機関でも非木材繊維の研究が主要 で, 工業省科学局 (Department of Science) の研究 部 (Research Division) では米の外殼からのパルプ, 竹パルプの評価がなされている。また, 総理大臣直轄 のタイ科学研究公社 (Applied Scientific Research Corporation of Thailand, 以下 ASRCT と略称す る)では, バガス, ケナフのパルプ化に重点を置いて いる。工業省の 研究部長の Vichien Sakornmonkol 氏の話では, 農家ではケナフの栽培から収入のよい夕 ピオカの栽培に切り替えるところが多く, 減産気味で あるとのことであるが，ASRCT の研究 I 副部長の Narong Chomchalow 博士は, 減産傾向は特に気に する必要はなく, ケナフのパルプ化の工業化が推進さ れれば生産量は上がってゆくといら意見を筆者に吐露 した。そのため, ASRCT ではケナフのパルプ化は最 重点課題である。

タイ国の木材資源に目をやると，同国の森林は降雨 量や地形から，(1) 熱帯降雨林，(2) 雨緑林，(3) 照葉林 に大別される。(1) はマングロープ林，(2) はチーク林， (3) はマツ林, ブナ林で代表される。タイの主要な木 材はチーク材であり，山林局 (Royal Forest Department）の入口にあるチーク材による象の彫刻像やそ の研究部門に所属する木材研究所 (Wood Research Institute) 及び Kasetsart 大学林学部の入口から 2 階 にかけて設置されているチーク材のサンプルからこ

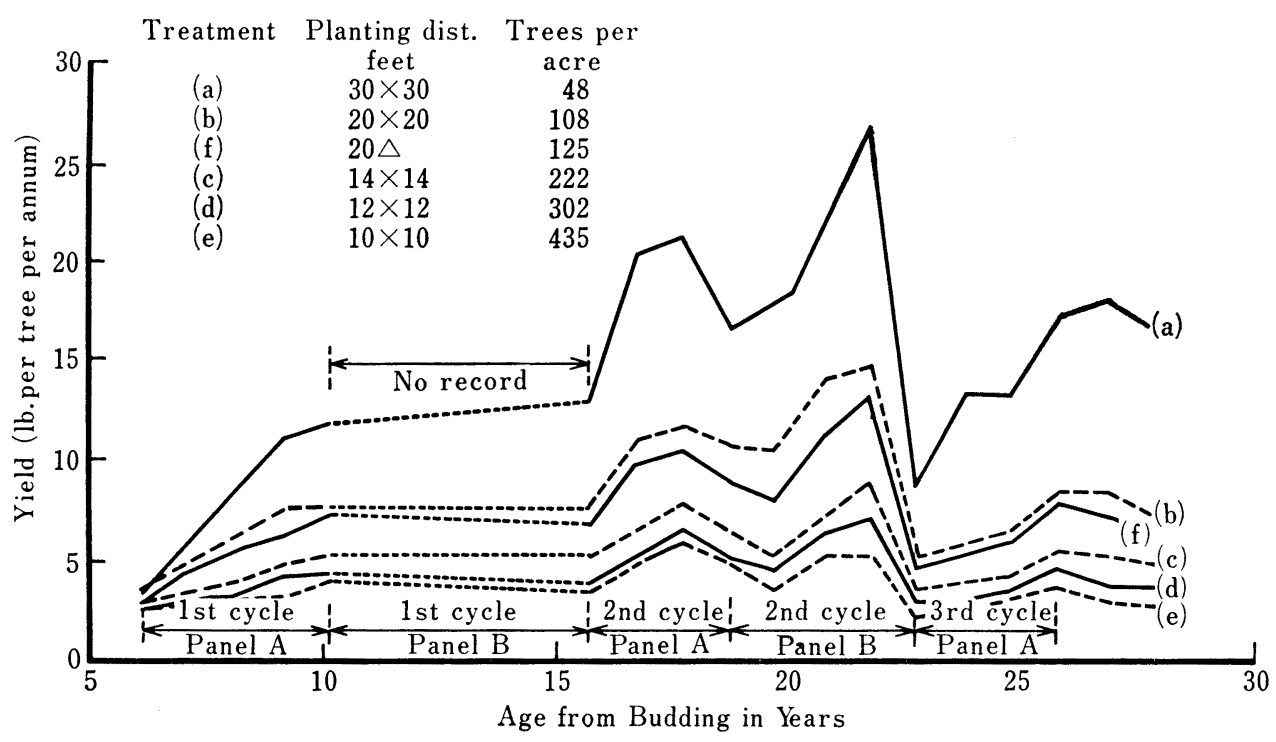

Fig. 2 Variation of Annual Yield of Rubber per Tree After Plantation 


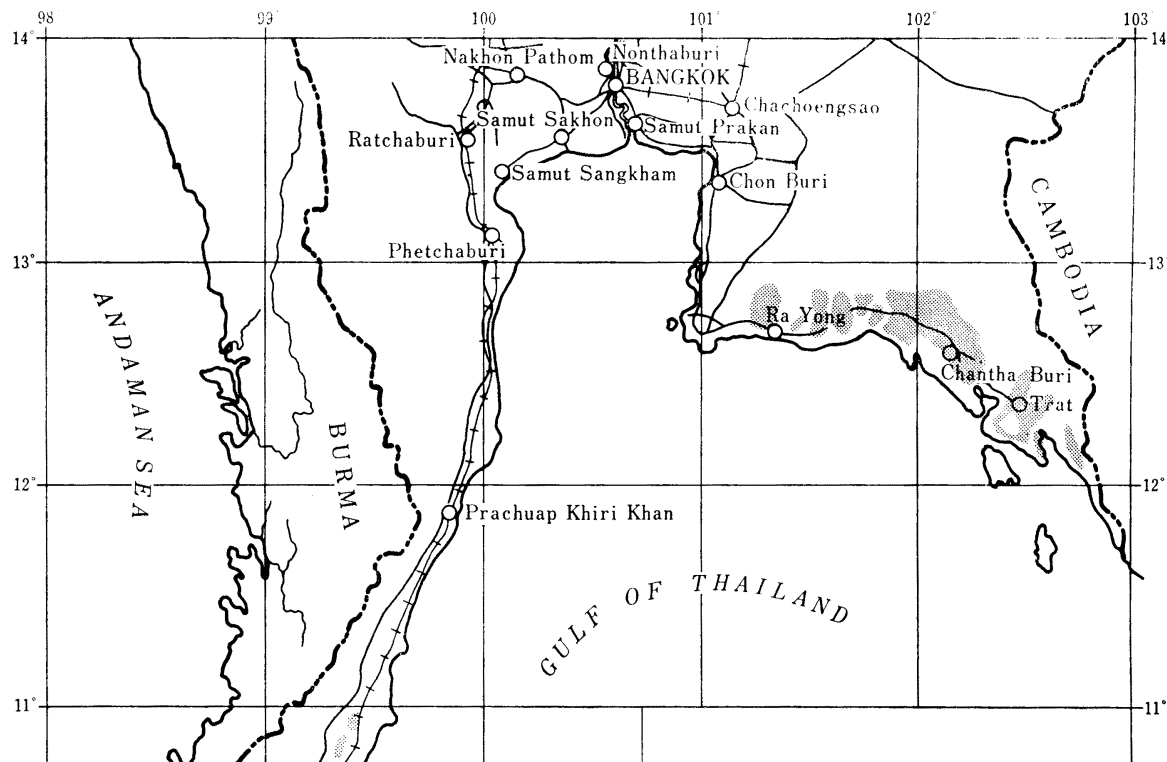

THE RUBBER GROWING AREAS OF THAILAND

PENINSULAR AND SOUTH-EAST THAILAND

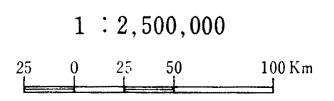

Principal Roads

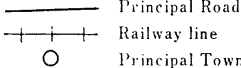

The Rubber Growing areas

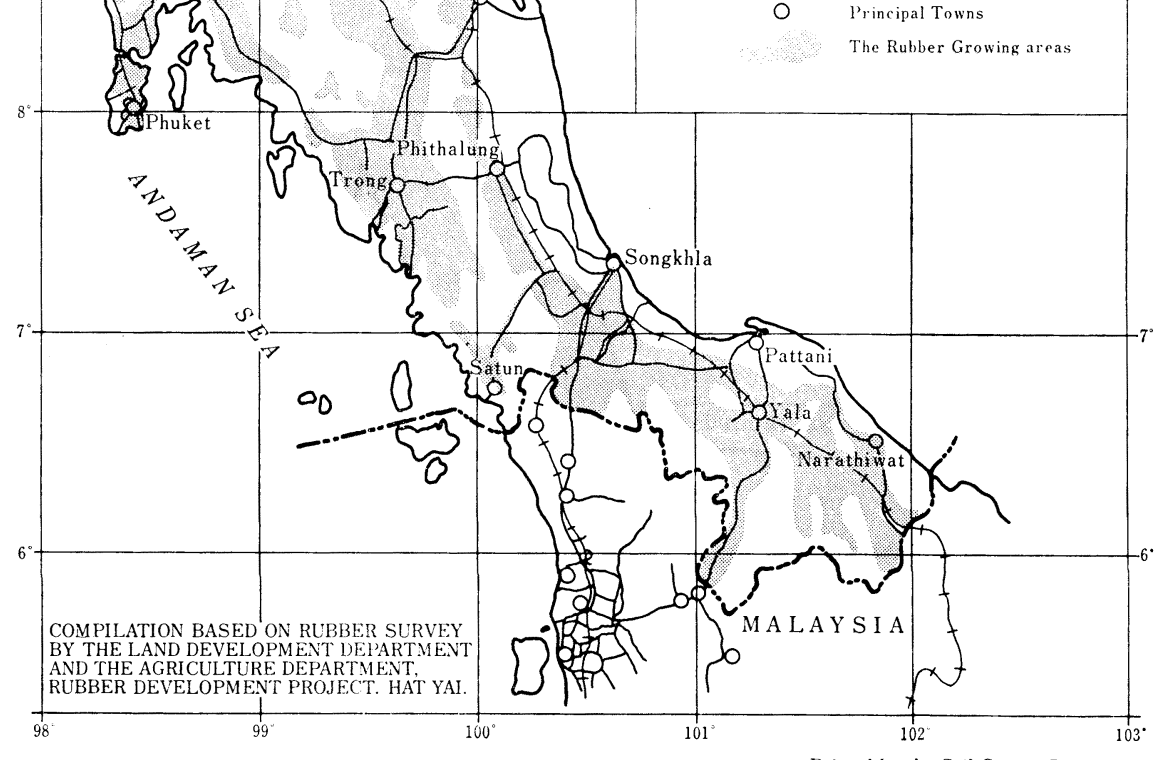

Printed by the Soil Survey Division, 1971

Fig. 1 The Rubber Growing Areas of Thailand 
れらの木材加工の研究としてチーク材に重点が置かれ ていることが分かる。マツは北部に 180,000 エーカー の植樹面積を有し，主要なパルプ資源として注目して いる上 ASRCT では㽞っている。また，パラゴムの 木は図 1 亿示すように南部及び半島部に片寄っており， 1972 年の 統計資料ではその栽培面積は東部 122,467 ha, 南部 1,118,519 ha, 計 1,240,986 ha であるとさ れている。この值はマレーシア連邦と比較すると 1 け た少ないが，重要な木材資源である。特に，パラゴム の木から生産するラテックス量は樹令とともに図 2 の 上うに変化し，25 30 年で廃材となる。山林局では この廃材の活用についての技術協力の要請を行なって いる。パラゴムの木のパルプ化及びその製紙特性につ いては，中山ら ${ }^{6)}$ の報告がある。

\section{3 民間企業ベースの技術嗳助要請計画}

現在民間企業ベースで推進されている技術援助計画 の主要なものは 3 つあるすなわち, Thai Newsprint Co., Thai Pulp Co. 及び Phoenix Pulp and Paper Mills Co. で計画中のものである。

\subsubsection{Thai Newsprint Co. の推進する計画}

同社は 1969 年 投資委員会から推進の承認を得たが, 北部の 112,000 ha に及ぶマッのコンセッション（伐採 取得地区）の利権を得るに至らず, また, 農業省山林 局ではマツの植え替え資金を保証する専有的な銀行融 資を要求していることも計画推進上の障害の主因にな っている。出資はタイ国側が $51 \%$ ，外国側が $49 \%$ で， 後者のうち, $25 \%$ をイスラエルの Eisenberg グルー プが持ち，その外，Thai Rath 社といらタイ国の日刊 新聞社に新聞用紙を供給している西ドイツの Kruger Co. も興味を持っているとのことである。生産開始を 3 年後に予定している。

\subsubsection{Thai Pulp Co. の推進する計画}

同社は竹パルプ利用の会社で, 1971 年に投資委員会 の認可を得たが，Kanchanaburi 管区での竹の植樹 (96,000 ha) のコンセッションを得るまでには至って いない。これは同社の工場の地の利が悪く, 且つ, 竹 の植樹費が高いことによる。資金としては 105 億円が 見込まれている。この計画は過去 3 年ぐづついていた が，総理大臣の介入で，近く実現のきざしがある。

\subsubsection{Phoenix Pulp and Paper Mills Co. の推進する計画}

インドでジュートのパルプ化の実績を持つBallapur Paper and Strawboard Mills の助力を得て, feasibility study を実施し, 年間 200,000 t の乾燥ケナフ 70,000 t からのケナフパルプを製造する予定にしてい る。資金は 150 億を見込み，らち，外国企業から $49 \%$
出資するものとしている。その主な出資先は Ballapur of India, European Overseas Development Corporation, Asiapac Fargo (Thailand) Co. 及び Overseas Securities and Consultants Co. 等である。 ケナフは Khoen Kaen 管区から供給を受け，1980 年までには処理能力を $270,000 \mathrm{t} /$ 年までもってゆきた いと希望している。

\section{4 夕イ国政府ベースの技術援助要請計画}

農業省山林局からは, 紙パルプ研究・工業化開発プ ロジェクトとパラゴムの木のパルプ化についての技術 援助が求められている。計画要請の責任者は同局林産 研究部 (Forest Products Research Division) に所 属する林産化学・化学技術課長の Sansern Charernsri 氏である。

\subsection{1 紙パルプ研究・工業化開発プロジェクト}

本プロジェクトの援助を求めている対象国あるいは 機関はSIDA, NORAD，日本政府，フィンランド政 府, カナダ政府, USOM, UNDP, UNIDO 等であ る。要請計画では, 1985 年のタイ国内の 紙需要量を $600,000 \mathrm{t}$ と見込み, マッ, 竹, パラゴムの木等の国内 資源で自給体制を確立しょうというものである。第 1 次計画は 1977 年 10 月 1986 年 9 月の 10 力年で, 植 林は $32,000 \mathrm{ha}$, 工場には 7,000 所帯 $(35,000$ 人) の タイ人の雇用と 20,000 所带 $(100,000$ 人)の山林農業 従事者を見込み, 更に, カセイソーダ, 塩素などの化 学薬品の使用量を年間 $60,000 \mathrm{t}$ と見積っている。計 画地域は次の 6 力所である : (1) 北部, Mae-hong-son, Cheing-mai, (2) 北部, Tak, Utadit, Pitnulok, (3) 東部, Nakorn-ruchsima, Khoen-kan, (4) 東北部, Burirum, Surin, Sri-Saket, Ubol-rachthai, (5) 西 部, Kanchanaburi, (6) 南部, Song-kla, Yala, Surathani。

プロジェクト参加要員としては, 現在の 7 名を 32 名に增員し，その中には製紙技術者のプロジェクトマ ネージャ一の外, 紙パルプ, 製紙, 機械, 経済の専門 家が各 1 名要請されている。装置費としてはパイロッ トプラント 2,100 百万ドルを見込んでいる。なお，第 1 次計画以降は自国で開発を推進できるとしている。

\subsection{2 パラゴムの木のパルプ化}

パラゴムの木の栽培面積は表 2 のように年々増加を 示し, 植え替え面積は年間 16,000 ha に達し, それか ら得られる廃材量は 1.9 百万 $\mathrm{m}^{3}$ に及ぶことから, $\mathrm{FAO}$ に対してその有効利用の技術開発の援助を要請 している。ここから得られた廃材の $1 / 4$ を利用だけで も, 唒パルプが 100,000 t も得られる計算になる。計 画は 1977 1981 年の 5 力年計画である。援助要請内 
Table 2 The Growing Areas of Para Rubber Tree in Thailand

\begin{tabular}{|c|c|c|}
\hline A. D. & $\begin{array}{c}\text { Plantation Area } \\
\left(\times 10^{3} \text { ha }\right)\end{array}$ & $\%$ of Original Area \\
\hline 1965 & 784 & 2.08 \\
1966 & 800 & 2.04 \\
1967 & 816 & 2.00 \\
1968 & 832 & 1.96 \\
1969 & 832 & - \\
1970 & 960 & 15.38 \\
1971 & 1,088 & 13.33 \\
1972 & 1,232 & 13.23 \\
\hline
\end{tabular}

容は，(1) 技術的ノウハウの研修，(2) 伐採廃材の利用 に関する情報，(3) 伐木，製材，合板工場から出る廃 材の利用に関する情報，(4) 伐採ゴムの木をパルプ工 業に応用する場合の feasibility study の実施，(5) ゴ ムの木のパルプ品質及び紙品質の 研究，(6) ゴムの栽 培地でない南部以外の地域で行なら場合の方法, に関 するものである。(2) (5)の目的のためには, 南部 14 管区のゴム林を 4 班の調査チームで研究することが必 要であると考えられている。調査研究には紙パルプの 経済の専門家と技術者が各 1 名, 1 年にわたって專従 することが必要であるとされている。なお，資金援助 は 250,000 ドルを要し, タイ国はその $1 / 10$ を負担し 得るとしている。

\section{5 紙パルプ研究機関とその研究テーマ}

タイ国政府の紙パルプ研究機関としては，次のもの がある：(1) 工業省科学局 (Department of Science) の研究部 (Research Division), (2) 農業省 (Ministry of Agriculture and Co-operatives) 林山局 (Royal Forest Department) 所属の林産物研究部門 (Forest Products Research Division), この中には木材研究 所 (Wood Research Institute) が併設されている, (3) 総理大臣直属のタイ科学研究公社 (ASRCT) であ る。その他，タイ国では主要な大学は 5 校あるが，林 学部のあるのは農科大学である Kasetsart 大学であ り,ここで紙パルプ関係の基礎的な研究を一部担当し ているが，それは繊維の研究の一環としてであり，メ インとなる研究ではない。上記の研究機関は, 工業省 の研究機関を除き，一区画にまとまって相互に隣接し ており, 密接な連絡がとられているようである。

\subsection{1 工業省科学局研究部}

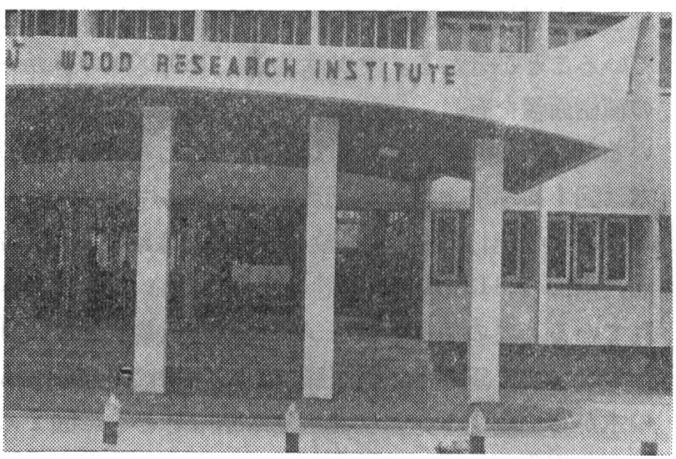

Fig. 3 Wood Research Institute in Thailand

本研究機関の 歴史は古く, 設立は 1891 年である。 業務内容はサービスと研究開発であり, 前者は分析, トラブルシュート等である。紙パルプ関係は後者に属 する。最近，工業標準研究部門がこの機関に併合，筆 者の訪問時, ほぼ建屋が完成していた。研究部長は, Vichien Sakornmonkol 氏である。本研究機関の職務 は，(1) 自国産原料の工業への利用に関する研究開発, （2）鉱工農林各業資源から生ずる廃棄物の利用，(3) 品 質改善, 生産効率化に対する支援, (4) 新プロセスの 創造と研修，(5) 公共への サービス等である。紙パル プ関係では, 米の外皮 (rice husk) のパルプ化, 竹パ ルプの評価などを研究している。紙パルプ関係の研究 要員は 6 名。 5 ち 1 名は若いが博士号を持っている。 研究設備は公設研究機関程度で, あまり高価なものは ない。研究が主務とはいえ, 各署からの依頼分析ある いはルーチンワーク的な性格を持つ業務が多い。例え ば輸入品の紙品質の評価係争時の紙パルプの判定など。 本機関は, 我々の国際研究協力に関してはかなり冷や かであった。

\section{5 .2 農業省山林局}

1896 年に発足した標記局には臨時職員を含めて, 3,500 名の職員がいて, 森林の行政にあたっている。 同局の研究業務の担当部署は林産物研究部であること は前述の通りである。この研究部に併設されている木 材研究所を図 3 に示寸。本研究部の職務は，(1) 木材 及びその他の林産物に関する研究，(2) 木材及びその 他の林産物の性質及び利用に関する研究，(3) 天然及 び工業資源から得られる製品の技術情報及び武料の収 集，(4) 国の経済に利するような利用法の考案及びそ の工業化等である。同研究部は更に 6 課に分かれてい るが，紙パルプ関係の研究を担当する課は林産物化 学・化学工業研究課 (Forest Products Chemistry and Chemical Technology Research Sub-division) 


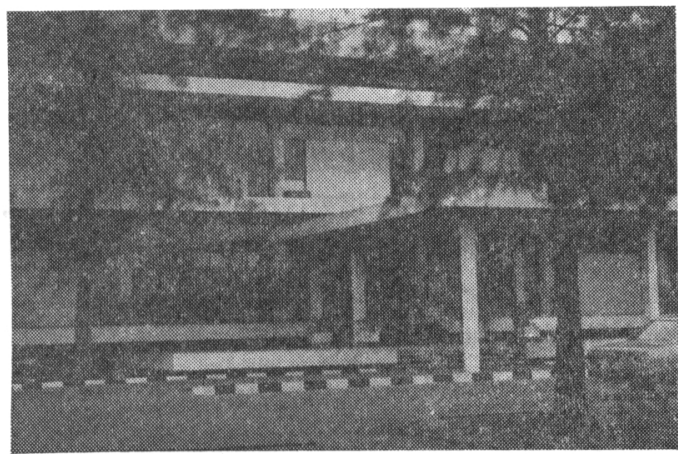

Fig. 4 Applied Scientific Research Corporation of Thailand

であり,その課長は東北工試に留学の経験を持つ Sansern Charernsri 氏である。紙パルプ 研究室は物 性測定室を含め 4 室で, 蒸解装置などは製材工場に設 置されていた。特徴的なことは作りがすべてドイッス タイルで, 機器類もほとんどが, ドイツ並びにフラン ス製である。日本製品が多くみられる東南アジアの研 究施設のなかにあって, 珍しいことである。これは同 研究所が 1967〜74 年にわたって西ドイツから技術援 助を受けていた影響であろらか。一国の技術援助の影 響力がいかに大きいかまざまざと見せつけられた思い である。

紙パルプについては，パラゴムの廃材の利用技術に 関する技術援助を望んでおり，それについては2.4.2 で記した。その他，マングロープ材，木の全体利用な どの話題もあがり, TMP についても関心が大きかっ た。

\subsubsection{ASRCT}

本研究機関の設立は新しく, 1963 年国王法 (Royal Act）により政府各部署の研究機関のコオージネータ 一的な色彩を持つ機関として設置された。そのため, 総理大臣の直轄下に置かれている。海外研究機関との 連携も密接である。研究機関としては発足が新しいだ けに, タイ国の研究機関のなかでは最も設備が整った 機関の 1 つであり，人材もそろっている感じである。 研究者自身も指導的機関の 1 つであるとい5自負を持 っている。本機関の概観を図 4 に示す。

紙パルプの研究では, 国営の紙パルプ工場が現実に 直面している問題などが持込まれて研究することも多 い。タイ国の資源面の利用に立脚した研究を行ってい て, 当面の課題としては, マッ, 竹, バガス, ケナフ 等の活用である。現在はこの中でも, バガス, ケナフ のパルプ化に重点を置いた研究を行なっている。紙パ

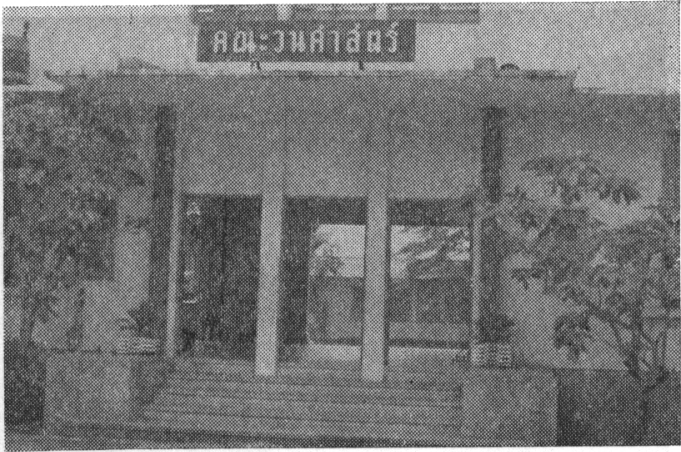

Fig. 5 The College of Forestry, Kasetart University in Thailand

ルプ関係の研究は同機関の化学技術グループの繊維及 び織布部門担当 (Fibers and Textiles Unit) で行な い, 責任者は副研究I部長の Narong Chomchalow 博士で, Ph. D の学位を持つ。人員構成は化学者 1 , 化学工学 1, Power Technologist 1, その他 MS 1 で, 研究補助者 3 名と合せて 7 名である。ASRCT は ITIT 事業に参画した経験を持ち, 副研究所長が一昨 年 (1976 年) 来日している。

\subsubsection{Kasetsart 大学林学部}

山林局や ASRCT と隣接し, 農科大学らしく㹡大 なキャンパスのなかに存在する (図 5)。林学部入口か ら階段にかけて, チーク材の見本が整然と並べてある のが印象的。筆者が会見した林学部長の Chongrak Prichanan 教授は木材加工が御専門である。同大学の 紙パルプ関係の講座は 40 余名の 学生がいるが, 基礎 的なことしか研究しておらず, 国際研究協力は前述の 山林局で行なっていると筆者を同局に紹介してくれた。 有機材料学を専門とするWiras Chunwarin 教授の話 では, 蒸解条件, 繊維長分布などの検討をしておられ るよらである。

\section{3. マレーシア連邦}

\section{1 紙パルプエ業の現況}

「人口のみが富豊である」といわれる東南アジア諸 国のなかにあって，マレーシア連邦は国民所得が香港 やシンガポールに次いで大きく, 経済的には比較的豊 かである。それは国の経済が豊かな天然資源に恵まれ， 1 次産品の輸出でまかなえるからである。世界 1 位を 跨るものとしては, 天然ゴム, すず, パーム油, 南方 材があり, その他, 石油は 2 位の輸出実績を目指して いる。このような自然の幸に恵まれた経済下にあって は，国内工業はほとんど育たず，紙パルプ工業も例外 


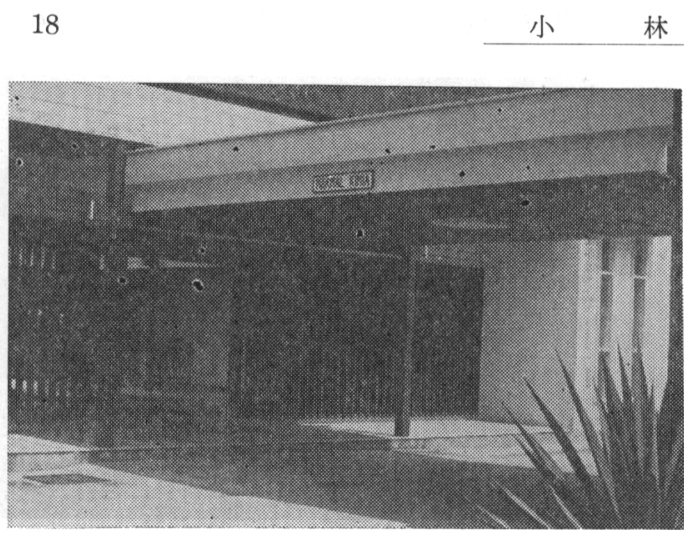

Fig. 6 Woodfiber Research Division in Forest Research Institute in Malaysia

ではあり得ない。もう一つ工業発展をはばんでいる要 因にマレー人優先主義がある。この国ではマレー人 $54.7 \%$, 中国人 $34.2 \%$ ，インド人 $9.0 \%$ ，その他 2.1 $\%$ といら人種構成である。政治の中枢はマレ一人が 占めてはいるが，経済の実権は中国人に握られている。 政府の要人のマレー人自体も収人のよい地位を求めて 転々とし, また, 企業経営者も転職防止のため, 従業 員に技術の全体をは握されることを極度におそれ, 全 ぼうを教えることを嫌い, そのため; 技術の蓄積, 工 業を育成する土壤がない。このような一般則は, 紙パ ルプ工業においても例外ではなく, 見るべき紙パルプ 工業はほとんどない。1974 年のデータでは機械パル プ 1,001.9 t (このらち, $906.7 \mathrm{t}$ をニュージランドか ら輸入), 化学パルプ $39.3 \mathrm{t}$ 晒 SP を $1,884 \mathrm{t}$ (この らち, カナダから $1,159 \mathrm{t}$, 米国から $60.2 \mathrm{t}$ を輸入) を輸入して，自国で製紙したに過ぎない。また，パル プメーカーとしてはカジャンに古紙再生の中しん原紙 工場（能力， 3,000 t / 年）があるだけである。大昭和 製紙㫼がジホールとポートクランに 2 力所工場を持ち, 南方材を輸送，パルプを持ち帰り製紙しているが，マ レーシア連邦政府が自国のチップ船の使用を強要した ため, コスト高になり, 現在ほとんど生産を止めてい る。

以上のような状態であるから，ほとんど紙製品は全 面輸入に依存しているといっても過言ではなく，その 量は $250,000 \mathrm{t} /$ 年である。1 1 当りの消費量に換算 すると約 $20 \mathrm{~kg} /$ 年である。この值はタイ国よりもかな り高く, 香港, シンガポール, 台湾に次ぐ順位である。

\section{2 民間企業ベースの技術援助要請計画}

マレーシア連邦は, 連邦政府とは別に地方州政府に 農工業の権限が支えられているので, 連邦政府とは別 に州政府の支援を得て, 紙パルプ工業を起そうという
計画が進められている。

\subsubsection{Pahang 州における計画}

この州では Pulp and Paper Mill Co. と Fibers and Chemicals 社の話が進められていた。前者はフラ ンス政府の援助のもとに進められていた計画であるが, 筆者が訪国した直前, その計画の中心人物が污職で捕 えられ，計画はペンディングになるであろうと，商工 省事務次官 Ahmad Bin Sa'adi 氏は筆者に話してく れた。一方，後者はインドと地元の業者との合弁会社 の計画であったが，山林局のコンセッションが得られ ず, 中止され, Johore 州に変更されたとのことであ った。

\subsubsection{Johore 州における計画}

Fibers and Chemicals 社は, 上記のようにPahang 州で行なら計画をJohore 州に変更した。本計画はイ ンドの Birla グループと地元資本家との合弁会社の形 で，520 億円の投資を予定し，紙及びレーヨン一貫工 場を建設する計画であり, 1975 年 9 月に商工省の認可 を得た。Birla グループは支払い済み資金 61.1 億円 のらち 30\%を投資し，L材からの製紙・レーヨン製 造技術を提供する。製紙能力は $104,000 \mathrm{t}$ / 年, 筆記用 紙, 印刷用紙, 塗工紙, クラフト紙, 包装紙などの 各種のグレードの紙を製造する。また，レーヨンは $12,000 \mathrm{t} /$ 年の能力で, ここで生産するレーヨンを上 質コットンの代替えにしようといら計画である。

\subsubsection{Perak 州における計画}

同州で生産するStraw Padi Straw (90,000 100,000 $\mathrm{t} /$ 年) を用いて, 10,000 t/年のわらパルプを生産す る計画に対して, feasibility study が(財) 日本プラ ント協会を中心に, 本州製紙株が参画して進められて いる。

\section{3 紙パルプ研究機関}

マレーシア連邦の紙パルプ 研究機関は, 山林局 (Forestry Department) に所属する林業試験所 (Forest Research Institute) のみである。この 3 月開所され たばかりのマレーシア標準工業研究所 (Standards and Industrial Institute of Malaysia) は, 基礎研究 の後工業の段階で品質管理といらことで関連するが, 基礎研究では関係がない。また農業試験所(Malaysian Agricultural Research and Development Institute) もまた, 紙パルプの研究はゴム以外関係がない。外に, 大学は Malaya 大学をはじめ 5 校あるが, 筆者は滞在 期間の関係で訪問できず詳細は不明である。

\subsection{1 林業試験所 (FRI)}

FRI は Kuala Lumpur 市から北西部に約 $16 \mathrm{~km}$ 離れた Selangor 州 Kepong にあり，1,500 エーカ 
一という臌大な面積を㩁し，山林の子もとにある。本 研究機関注第 1 工業省 (Ministry of Primary Industries）の西マレーシア連邦の山林局の研究部門で, 1925 年林業関係の独立した 研究機関を設置する計画 が提案され，1929年に開所した。化学部門の設置は 1954 年である。紙パルプの研究は木材繊維研究部 (Woodfiber Research Division) で行なわれている (図6)。同所のスタッフは 72 名, 研究補助者 82 名, 学務者 166 名。紙パルプの要員はスタッフ1名, 研究 補助者 1 名で弱体である。責任者はPeh Teik Bin 氏 である。紙パルプに関連し，本連邦の要望は溶解パル プレーヨンの製造技術に関するものが極めて大きく, 筆者が訪問した政府機関のいたるとろこで，その研究 協力の要請を受けた。また, Wood Extraction など のテーマも要請された。しかし, 根本的な研究協力の 要請としては紙パルプ研究体制を整えることで, その 一般的な計画と設計に助力してほしいといらことであ る。紙パルプ研究を根本から打ち立てるといら意味か らすれば, 意義ある研究協力といえるかも知れない。 現在の紙パルプ研究室は化学研究室 2 , 物性研究室 1 , その他蒸解機は製材工場に置かれていたことは夕イ国 と同じであった。

\section{4. おわりに}

以上でタイ国及びマレーシア連邦の紙パルプに関す る現状と将来計画を技術援助の要請, 国際研究協力と いら観点を中心に述べた。我が国では資源の制約，公 害規制の面から工場立地化多くの難点が生じてきてい
る。一方，発展途上国は概して資源はあるが，技術に 欠ける。そのため，今日で汢工業は製品輸出から対外 淔接投資時代を迎えた。これは，別の視点からすれば， 紙パルプ工業の雁行形態的後退過程》を具現化してい るものともいえる。拙稿が紙パルプ工業の今後の進展 の一助になれば，筆者の望外の幸せである。

\section{謝辞}

調査にあたり, 工業技術院総務部国際協力官室, 在 タイ日本大使館, 在マレーシア日本大使館, 地質調查 所 UNDP 勤務の 河田清雄, 嶋崎吉彦両博士，丸紅 㥪バンコック支店及びクアラルンプール支店, 日本商 工会議所クアラルンプール事務所の方々等多くの在外 邦人の方々のご支援を頂いた。特にタイ国にあっては， 丸紅検バンコック支店羽田雄飛氏, マレーシア連邦代 あっては在マレーシア日本大使館横田捷宏氏, 日本商 工会議所クアラルンプール事務所長大竹伸幸氏に多大 のご尽力を頂いた。記して東心から感謝の意を表した い。

\section{参考文献}

1）田中康夫，紙八技協誌，16，410（1962）。

2) 関: 義城, 同誌, 11，266 (1957).

3）小泉信義，紙パ技術タイムス，7(9)，19(1964).

4）森 博，紙パ技協誌，24，59 (1970).

5）小林良生, 同誌, 31, ([977).

6) 中山和夫, 白井 健, 平石秀三, 小野里啓機, 同 誌, 26, 323 (1972).

7）大野泰雄，高分子， 21(238)，3 (1972). 